\title{
Adoption of Chemical Fertilizer for Land Management in the North-West Zone of Nigeria
}

\author{
*M.G. Maiangwa, A.O. Ogungbile, J.O. Olukosi and T.K. Atala \\ Department of Agricultural Economics and Rural Sociology, Institute for Agricultural Research, \\ Ahmadu Bello University, Zaria
}

Accepted $15^{\text {th }}$ August 2007

\begin{abstract}
The study aimed at: (i)estimating the rates of adoption and application of inorganic fertilizer; and (ii)determining the farmer-and farm-characteristics conditioning the adoption of inorganic fertilizer in two selected States in the north-west zone of Nigeria, namely, Kano and Katsina States. A two-stage sampling procedure was adopted in the survey, First, two Agricultural Development Programme (ADP) zones were purposively sampled in each State on the basis of relative climate. In Kano State, Rano and Danbatta zones were chosen, while in Katsina State, Funtua and Ajiwa zones were selected. Second, 60 farmers were randomly selected from each of the four ADP zones giving a total sample size of 240. The results of the survey showed that the mean rates of adoption of inorganic fertilizer were $85.85 \%$ for Kano, $98.35 \%$ for Katsina, and $92.10 \%$ for both States. These rates of adoption were illustrative of a long history of exposure to fertilizers. The mean rates of application of inorganic fertilizers of $41.49 \mathrm{~kg} \mathrm{ha}^{-1}$ for Kano, $67.24 \mathrm{~kg} \mathrm{ha}^{-1}$ for Katsina and $54.36 \mathrm{~kg} \mathrm{ha}^{-1}$ for both States were, however, short of the recommended nutrient levels for the staple food crops grown in the two States. The result of the analysis of the socio-economic factors conditioning adoption of inorganic fertilizer showed that all the factors included in our model influenced the adoption of inorganic fertilizer, but there were locational differences in the significance of these factors. Recommendations made included: the complementary applications of inorganic and organic fertilizers; the adoption of integrated soil fertility management practices; training extension educators and other technical assistants to understand the factors conditioning adoption for more effective targeting and delivery of programmes; the education of the rural populace, encouraging membership of farmers' associations; the expansion of farm sizes; improved access to production credit; and the strengthening of existing extension systems.
\end{abstract}

Key words: fertilizer, adoption rate, application rate, adoption factors, Nigeria

\section{INTRODUCTION}

Developing countries face the dual tasks of increasing agricultural productivity and ensuring sustainability of the resource base on which agriculture fundamentally depends (Ersado et al., 2004). The usual means to achieve these goals are through public investments with financial support from government agencies or non-governmental organizations (Ersado et al., 2004). Often, these investments take the form of incentives to adopt improved technologies, the argument being that growth in agricultural production should come from yield increases rather than area expansion (Eicher, 1994). For most sub - Saharan African countries, adoption of more efficient farming practices and tech-

\footnotetext{
*Corresponding author
}

nologies that enhance agricultural productivity and improve environmental sustainability, particularly as the land frontier is reduced under growing population pressure, remains the most practical option for achieving economic growth, food security, and poverty alleviation (Ersado et al., 2004).

Over the past 25 years, the primary means of enhancing soil fertility in small - farm agriculture has been to use chemical fertilizers (Byerlee and Heisey, 1992).Given also the present knowledge, the limited scope for expanding cultivated area, the rapid rate at which food production must increase in developing countries, severe soil degradation, and the prospect that future increases in cereal production will mainly depend on increased crop yields, or 
what is known as "agricultural intensification," fertilizer will remain an essential input in meeting the future food production requirements and farmers probably will have little choice but to depend heavily on external sources of nutrients in the foreseeable future (Desai, 1990; Byerlee and Heisey, 1992; Mitchell and Ingco, 1993; FAO, 1993; Pinstrup-Andersen and Pandya - Lorch, 1994; Rosegrant et al., 1995).

An important first step towards determining the impact of a technology on a target society is to obtain some idea about the rate of diffusion or adoption of the technology and its related components (Phillip et al., 2000). This information, in addition to serving as input into future technology impact assessment processes, can also provide a useful feedback for strengthening the research-extension - farmer linkage (Idisi, 1990). Similarly, though many producer technology adoption studies have been conducted in developing countries, the importance of factors affecting technology adoption differ across countries, on account of variations in natural resource endowments, as well as cultural political, and socio-economic differences (Feder et al., 1985; Heisey and Mwangi, 1993). A review of technology adoption studies in Africa has also shown that factors influencing adoption differed by location (Heisey and Mwangi, 1993). Besides, in the northern parts of Nigeria, there have not been many systematic and documented scientific studies of the relationship between these factors and adoption of farm innovations (Atala, 1988). Research into farm household investment and adoption behaviour has also been found useful for technology development and design of policies and strategies that promote resource-conserving land use (Shiferaw and Holden, 1998).

This paper broadly aims at providing information on the technology adoption behaviour of farmers in the north-west zone of Nigeria. The specific objectives are to estimate the rates of adoption and application of chemical fertilizer, determine the socio-economic characteristics of farmers which are related with adoption of chemical fertilizer and recommended ways for strengthening the observed technology adoption behavior in the study area. The paper is divided into 5 sections. Section 1 is the introduction. Section 2 reviews in brief the contribution of chemical fertilizer to food security and resource/environmental conservation. Section 3 contains the methodology. The results and discussions are presented in Section 4 and the conclusion and recommendations in Section 5.

\section{Contribution of fertilizer to food security and resource/environmental conservation}

Fertilizer contributes to increased food production and in the reversal of the downward spiral of population pressure and environmental degradation in several ways, namely:

i. fertilizer can provide much needed nutrients to the soil, thereby maintaining and enhancing soil fertility and thus increasing crop yields and food production;

ii. fertilizer enables adoption of high-yielding varieties (HYVs), which can increase cereal yields several fold, hence without a plentiful supply of nutrients through fertilizer and other associated inputs, HYVs cannot produce higher yields;

iii. in the nutrient-poor soils of the tropics, more crops mean more biomass (living matter above and below the ground) to be ploughed back to maintain or augment the supply of organic matter (living and dead matter in the soil) and vegetative cover, thus enhancing moisture retention, nutrient use efficiency and soil productivity, and also reducing soil erosion when crop residues are used as a soil cover;

iv. by increasing crop production through fertilizer use in high-potential areas (those with better soils and favourable agroecological conditions), pressure to clear habitat-rich forests for crop production can be reduced;

v. a one-time, heavy application of phosphate rock and lime, followed by annual maintenance applications of fertilizer, can enhance and sustain the productivity of acid soil, which has considerable potential for food production in many developing countries;

vi. a one-time, heavy application of phosphate rock and lime, followed by annual maintenance applications of fertilizer, can enhance and sustain the productivity of acid soil, which has considerable potential for food production in many developing countries;

vii. since leguminous crops are an important source of protein for the poor in developing countries, increasing their productivity through phosphate fertilizer could improve human nutrition and enhance soil productivity;

viii. fertilizer makes an important contribution to intergenerational equity by preserving and 
sustaining the natural resource capital in the soils; and

ix. fertilizer use helps reduce global warming by enhancing sequestration of carbon in the organic matter of soils, since higher crop yields and biomass accumulation obtained through the application of fertilizer result in absorption of more carbon dioxide, a portion of which is held in soil organic matter (IBSRAM, 1987; Brady, 1993; Chien et al., 1993; Sombroek, 1994; Bumb and Baanante, 1996).

\section{METHODOLOGY}

The study was conducted in two States in the NWZ of Nigeria, namely: Kano and Katsina. These States are considered representative in terms of biophysical characteristics and population density for the larger part of northern Nigeria (Ogungbile et al., 1999).In addition, these States have a high agricultural production potential (NARP, 1995). The actual survey, however, took place in the Rano and Danbatta Agricultural Development Programme (ADP) zones of Kano State and the Funtua and Ajiwa ADP zones of Katsina State. These ADP zones were purposively selected with one situated in the northernmost and driest parts of a State and the other in the southernmost and wettest parts (Table 1). These ADP zones have also served as benchmark sites for participatory researches and for collecting diagnostic data and validating new and improved technologies, with their results often extrapolated to other areas with similar agroecological and socio-economic conditions (Ogungbile et al., 1999). The unit of analysis was the individual farm operator. The frames or lists of the farm operators were obtained from the monitoring and evaluation units of each of the four ADP zones (Table 1). For each ADP zone, a sample of sixty farmers was randomly selected. Thus, a total sample size of two hundred and forty farmers was ob-

\section{Table 1: Distribution of farmers in Kano} and Katsina States of Nigeria

\begin{tabular}{cccccc}
\hline State ADP Relative & $\begin{array}{c}\text { Headquarters } \\
\text { climate } \\
\text { of extension } \\
\text { sevices }\end{array}$ & $\begin{array}{c}\text { Total } \\
\text { Number of of farmers } \\
\text { farmers }\end{array}$ & $\begin{array}{c}\text { Number } \\
\text { selected }\end{array}$ \\
\hline Kano & I & Wet & Rano & 34,394 & 60 \\
& II & Dry & Danbatta & 35,032 & 60 \\
Katsi & I & Dry & Ajiwa & 34,543 & 60 \\
na & II & Wet & Funtua & 34,440 & 60 \\
\hline
\end{tabular}

tained. A structured questionnaire was used for the field interviews. The farm-level data collected between 2002 and 2003 were basically on the socio-economic characteristics of the farm operators, the rates of application, and extent of awareness and adoption of inorganic fertilizer for land conservation.

\section{Calculation of inorganic fertilizer adoption rates}

Three methods are established in literature for the calculation of technology adoption rates. In one method, and where crops are involved, the adoption rate is the ratio of the land area under the technology of interest to the total area under the crop in reference, multiplied by 100 percent. Studies in this category include Akino and Hayami (1975), Ahmed and Sanders (1991) and Lopez-Pereira et al., ( 1991). In these and related studies, adoption rates are computed within the broader objective of assessing the economic impact of researchgenerated technologies, and under the assumption that adoption follows some logistic trend or behaviour (Phillip et al., 2000). This assumption enables the researcher to project future adoption rates along a logistic curve, using observed adoption rates for some initial years of technology introduction (Phillip et al., 2000).

A second method refers to adoption as the use by farmers of a number of improved practices and is usually measured by an adoption score (number of improved practices used) or by an adoption quotient (number of improved practices used over total number of recommended practices) (Herdt and Capule, 1983). Scores may be arbitrarily scaled to arrive at some categorization of adoption, for example, low, medium and high (Ramaswamy, 1973).

The third method multiplies the ratio of adopting farmers to the total farmers in the sample by 100 percent (for example, Floyd et al., 999). This method is very popular mainly because of its simplicity and is adopted in this study in computing adoption rate.

\section{Modeling farmers' decision to adopt inor- ganic fertilizer for land management pur- poses}

The decision of a farmer to adopt inorganic fertilizer is influenced by a number of different 
factors that include the biophysical conditions of the farm, certain characteristics of the farmer and the farm household, and the institutional settings under which the farm operates (Rogers and Burdge, 1977; Coughenour, 1988; Zurek, 2002). In addition, farmers' perception of technology-specific characteristics and/or on the benefits and drawbacks of a technique are also important in this respect (Adesina and Zinnah, 1993; Shiferaw and Holden, 1998). Commonly explored farm characteristics influencing adoption include farm size, land tenure and other biophysical traits (Rahm and Huffman, 1984; Nowak, 1987; Baidu-Forson, 1999). Household characteristics include gender, age, education of household head, family size and other demographic traits (Clark and Akinbode, 1968; Alao, 1971; Nkonya et al., 1997; Ersado et al., 2004). Institutional factors include credit constraints, availability of information, and availability of extension services (Clark and Akinbode,1968; Alao, 1971; Voh, 1979; Atala, 1988; Ersado et al., 2004). Farmers perception of technology attributes include productivity, soil retention, sustainability, taste, yield, ease of cooking, ease of threshing and tillering capacity (Norris and Batie, 1987; Ashby et al., 1989; Gould et al., 1989; Ashby and Sperling, 1992; Adesina and Zinnah, 1993; Adesina and Baidu-Forson, 1995; Shiferaw and Holden, 1998). This study focuses on the institutional and farm-and farmer-specific factors influencing the adoption of inorganic fertilizer for land management. The choice of explanatory variables is, therefore, based on an extensive review of factors affecting adoption of agricultural technologies in low-income countries as contained in innovation-diffusion literature for explaining adoption decisions. The dependent variable is the quantity of inorganic fertilizer in kilogrammes applied per hectare, consistent with the approach adopted by Ranaivoarison (2004) in Madagascar. The dependent variable is thus a continuous one, allowing tests of various functional forms. The applicability of two specific types of models, namely, the linear and the logarithmic models was tested. Compared to the other models such as the Translog, quadratic and square root models, the linear and logarithmic models are mathematically easy to manipulate and economically easy to interpret (Ranaivoarison,2004). The linear and logarithmic models are separately run against the following institutional, farmer-and farm-specific factors: age, household size, education, membership of associations, farm size, credit, offfarm income, extension contact and land security. The definitions, units of measurement and hypothesized signs of the explanatory variables are given in Table 2. The linear and logarithmic models are of the following explicit forms:

(i) Linear: $Y=b_{0}+b_{1} X_{1}+b_{2} X_{2}+b_{3} X_{3}+b_{4}$ $X_{4}+b_{5} X_{5}+b_{6} X_{6}+b_{7} X_{7}+b_{8} X_{8}+$ $\mathrm{b}_{9} \mathrm{X}_{9}+\mathrm{e}$

(ii) Semi-log: $Y=b_{0}+b_{1} \log X_{1}+b_{2} \log X_{2}+$ $b_{3} \log X_{3}+b_{4} \log X_{4}+b_{5} \log X_{5}+b_{6}$ $\log \mathrm{X}_{6}+\mathrm{b}_{7} \log \mathrm{X}_{7}+\mathrm{b}_{8} \log \mathrm{X}_{8}+\mathrm{b}_{9}$ $\log \mathrm{X}_{9}+\mathrm{e}$.

(iii) Double-log: $\log \mathrm{Y}=\mathrm{b}_{0}+\mathrm{b}_{1} \log \mathrm{X}+\mathrm{b}_{2} \log$ $X_{2}+b_{3} \log X_{3}+b_{4} \operatorname{lo} X_{4}+b_{5} \log X_{5}+$ $\mathrm{b}_{6} \log \mathrm{X}_{6}+\mathrm{b}_{7} \quad \log \mathrm{X}_{7}+\mathrm{b}_{8} \log$ $\mathrm{X}_{8}+\mathrm{b}_{9} \log \mathrm{X}_{9}+\mathrm{e}$

where: $b_{0}=$ constant; $b_{i}=$ coefficients; $e=$ error term and $\mathrm{Y}$ and $\mathrm{X}_{\mathrm{i}}$ are as defined in Table 2.

\section{RESULT AND DISCUSSIONS}

\section{Adoption and application rates of inorganic fertilizer}

The adoption rates for inorganic fertilizer in Kano and Katsina States are shown in Table 3. The mean rates of adoption of 85.5 per cent for Kano, 98.35 percent for Katsina and 92.10 percent for the two States are both illustrative of a long history of exposure to fertilizers and also supportive of findings from other studies such as those of Voh (1979), Atala and Abdullahi (1988), and Musa and Atala (2004). According

\section{Table 2: List of independent variables used in the regression models and their units and expected signs}

\begin{tabular}{llc}
\hline \multicolumn{1}{c}{ Variable } & \multicolumn{1}{c}{ Unit } & $\begin{array}{c}\text { Expected } \\
\text { Sign }\end{array}$ \\
\hline Age $\left(\mathrm{X}_{1}\right)$ & Years & + \\
Household size $\left(\mathrm{X}_{2}\right)$ & Number of persons & - \\
Education $\left(\mathrm{X}_{3}\right)$ & Years & + \\
Membership of asso- & & + \\
ciations $\left(\mathrm{X}_{4}\right)$ & Years & + \\
Farm size $\left(\mathrm{X}_{5}\right)$ & Hectares & + \\
Credit $\left(\mathrm{X}_{6}\right)$ & Naira (\#) & + \\
Off-farm income $\left(\mathrm{X}_{7}\right)$ & Naira (\#) & + \\
Extension contact $\left(\mathrm{X}_{8}\right)$ & Number of visits & + \\
Land security $\left(\mathrm{X}_{9}\right)$ & Number of plots & + \\
& owned & + \\
\hline
\end{tabular}


to Enwezor et al., (1989), the first recorded indication of the potential values of inorganic fertilizers in Nigeria was in 1937 when it was shown that response of cereal crops to small applications of farm yard manure (EYM) was matched by the use of single superphosphate (SSP) containing quantities of phosphate equivalent to that in the organic manure, and that by the early 1930 s, fertilizer recommendations mostly based on research information, had been established for some of the important crops in Nigeria. A related argument by Voh (1979) is that modern fertilizer has been widely adopted because it has been in use for quite a long time and that farmers may have seen it and would have been convinced of its effectiveness. He cited studies by Basu (1969) and Byrnes (1966) to have shown that if farmers are convinced of the value of an innovation, they will adopt it.

The demand for fertilizer is itself determined by its economic value at the farm level, most commonly measured by the benefit - cost ratio (Lele et al., 1989). The long history of fertilizer subsidy in Nigeria, dating back to 1937 (Akpoko and Yiljep, 2000), may have also contributed to rapid growth in its use on a continuous basis; for example, some of the justifications for subsidies are that: they help poor farmers; encourage learning by doing; reduce the risk of using fertilizer and help overcome credit constraints; contribute to maintaining soil fertility; and offset disincentives caused by taxation of output (World Bank, 1986). The rates of application of inorganic fertilizer in Rano, Funtua and Ajiwa zones (Table 3) are similar to those obtained for some selected villages in Kano and Katsina states by Ogungbile et al., (1999) in a participatory rural appraisal

Table 3: Rates of adoption and application of chemical fertilizer in Kano and Katsina States, 2002 / 2003

\begin{tabular}{lcc}
\hline State/Zone & Adoption (\%) & Application $\left(\mathbf{k g ~ h a} \mathbf{~}^{\mathbf{~}}\right.$ \\
\hline Kano: & 96.7 & 68.5 \\
Rano & 75.0 & 14.5 \\
Danbatta & 85.8 & 41.5 \\
Mean & & \\
Katsina: & 100.0 & 51.6 \\
Funtua & 96.7 & 82.9 \\
Ajiwa & 98.3 & 67.2 \\
Mean & 92.1 & 54.4 \\
Mean & & \\
(bothStates) & & \\
\hline
\end{tabular}

survey conducted between September and October 1996 (Table 4). The application rate of 14.51 Kg ha ${ }^{-1}$ for Danbatta zone (Table 4), is however, comparable to those estimated for the African continent of between $10-18 \mathrm{Kg} \mathrm{ha}^{-1}$ of cropland by Bumb and Banaante (1996), FAO (1997) and Barbier (1998). Overall, the application rates in individual locations and the mean rates in each State and in both States (Table 4) fall short of the recommended nutrient levels for some staple food crops such as $200-300 \mathrm{~kg} \mathrm{ha}^{-1}$ for sorghum, 100-200kg nutrient ha ${ }^{-1}$ for millet and $220-300 \mathrm{~kg}$ nutrient ha ${ }^{-1}$ for maize (Onwueme and Sinha, 1991; JARDA, 1996). The implication is that fertilizer use in the sampled locations is low compared with the requirements of crops. Barbier (1998) attributes the poor productivity of African agriculture to the comparatively low level of use of external inputs. Reardon et al., (1999) also point to the low use of fertilizer across Africa as a major cause of concern, from both the food-production and the environmental perspectives. The authors particularly argue that the widespread "capital-deficient" unsustainable intensification in Africa is a major force behind farmland degradation and productivity loss. They described "capital-deficient intensification" as the process by which a farmer depends inordinately on labour-unassisted by improved technologies-to increase productivity, some aspects of which include cropping more densely, weeding and harvesting assiduously and so forth, and that, over time, this type of intensification depletes soils' nutrients and cannot be sustained without a shift toward "capital -led" investments such as the application of inorganic fertilizers.

Table 4: Fertilizer quantities used by farmers in Kano and Katsina States of Nigeria (PRA Survey 1996)

\begin{tabular}{cc}
\hline State/Village & Inorganic Fertilizer $\left(\mathbf{k g ~ h a}^{\mathbf{- 1}}\right)$ \\
\hline Kano & 68.1 \\
Kofa & 77.3 \\
Panda & 95.0 \\
Badume & 80.1 \\
Mean & \\
Katsina & 70.6 \\
Gora & 114.0 \\
Rimaye & 58.5 \\
Barhim & 81.0 \\
Mean &
\end{tabular}

Source: Ogungbile et al., 1999. 
Table 5: Estimates of regression models explaining factors affecting adoption of inorganic Fertilizer

\begin{tabular}{cccccc}
\hline Variables & Rano (Linear) & $\begin{array}{c}\text { Danbatta } \\
\text { (Double-log) }\end{array}$ & $\begin{array}{c}\text { Funtua } \\
\text { (Double log) }\end{array}$ & $\begin{array}{c}\text { Ajiwa } \\
\text { (Double-log) }\end{array}$ & $\begin{array}{c}\text { Pooled (Double- } \\
\text { log) }\end{array}$ \\
\hline $\mathrm{X}_{1}$ & -2.84298 & 0.46589 & $-2.04581^{*}$ & -0.41777 & $-1.30579^{* *}$ \\
& $(1.89534)$ & $(0.40509)$ & $(0.85459)$ & $(0.38923)$ & $(0.45334)$ \\
$\mathrm{X}_{2}$ & -1.37571 & -1.13083 & $-0.68856^{*}$ & $-0.51918^{* *}$ & $-0.49362^{* *}$ \\
& $(3.71441)$ & $(0.12764)$ & $(0.28314)$ & $(0.13739)$ & $(0.14538)$ \\
$\mathrm{X}_{3}$ & -5.94942 & -0.07043 & $0.11774 *$ & 0.03551 & 0.03532 \\
& $(3.84858)$ & $(0.02651)$ & $(0.05760)$ & $(0.02300)$ & $(0.03040)$ \\
$\mathrm{X}_{4}$ & 8.17083 & -0.04706 & $0.14932^{* *}$ & 0.01115 & $0.06138^{*}$ \\
& $(3.91300)$ & $(0.03326)$ & $(0.05455)$ & $(0.02345)$ & $(0.03035)$ \\
$\mathrm{X}_{5}$ & 12.57648 & 0.44270 & 0.23095 & $0.27290^{* *}$ & $0.42239^{* *}$ \\
& $(10.26023)$ & $(0.15634)$ & $(0.20189)$ & $(0.09393)$ & $(0.13294)$ \\
$\mathrm{X}_{6}$ & 0.01171 & 0 & 0.01166 & 0.02748 & $0.08325^{* *}$ \\
& $(0.00366)$ & $(0)$ & $(0.02962)$ & $(0.01769)$ & $(0.02287)$ \\
$\mathrm{X}_{7}$ & 0.00018850 & -0.03403 & $-0.04946 *$ & 0.00274 & $-0.03911^{* *}$ \\
& $(0.00025353)$ & $(0.01697)$ & $(0.02076)$ & $(0.01017)$ & $(0.01174)$ \\
$\mathrm{X}_{8}$ & -6.45984 & 0.02624 & -0.02929 & $0.16535^{* *}$ & 0.01054 \\
$\mathrm{X}_{9}$ & $(5.19081)$ & $(0.05887)$ & $(0.11034)$ & $(0.05649)$ & $(0.06360)$ \\
Intercept & -24.16039 & -0.60204 & -0.01639 & $-0.48053^{* *}$ & $-1.03349^{*}$ \\
$\mathrm{R}^{2}$ & $(16.28407)$ & $(0.23397)$ & $(0.31044)$ & $(0.13015)$ & $(0.15366)$ \\
& 193.38871 & 3.34436 & 13.67814 & 6.13898 & 10.15527 \\
\end{tabular}

\section{Factors influencing the adoption of inor- ganic fertilizer}

The results of the ordinary least squares regression model indicating factors determining the adoption of inorganic fertilizer are shown in Table 5. All the variables included in the OLS models were found to be significantly related with the adoption of chemical fertilizer, though there were locational differences in the significance of the variables (Table 5). The age variable, consistent with expectation, was positively related with adoption in Danbatta zone, but was negatively related in Funtua (where it was also significantly related), Rano, and Ajiwa zones as well as in pooled result for the sampled locations. A positive coefficient for age means that the older the farmer, the greater the adoption of inorganic fertilizer.

This is expected because actual usage of inorganic fertilizer by farmers commenced in the late 1940s when the West African Oilseed Mission recommended the supply of phosphatic fertilizers to boost groundnut production (Enwezor et al., 1989). The argument is that more experience and knowledge of the farming system associated with age is expected to have a positive effect on adoption (Shiferaw, and Holden, 1998; Lapar and Pandey, 1999). A negative sign for age implies that older farmers are less likely to adopt inorganic fertilizer than younger ones. Younger farmers have longer planning horizons and are therefore much more likely to adopt inorganic fertilizer (Lapar and Pandey, 1999). A number of studies (Voh, 1979; Hoover and Wiitala, 1980; Akpoko and Yiljep, 2000; Manyong et al., 2000) have shown age to have a negative influence on adoption. These results are at variance with those of Liao, 1968; Mangahas, 1970; Suh, 1976; Islam and Halim, 1976; Chinnappa, 1977; and Yim 1978), who found adoption to be generally unrelated to farmers' age. The household size variable, as expected, was negatively related to adoption in all the four sampled locations but was significantly and negatively related only in Funtua zone and in the pooled result. A negative sign for household size suggests that adoption was higher among smaller households. This might be because larger households attach greater importance to food security than small ones, hence will commit less resources to the adoption of inorganic fertilizer. This is supported by Shiferaw and Holden (1998) to the effect that, for a given land-man ratio, households with large families may perceive a higher risk of starvation than those with smaller families, and that if crops fail due to bad weather, households with larger families will suffer more and would therefore be much less in- 
clined to invest resources in inorganic fertilizer. These results contrast with that of Bhati (1975) who found a positive effect of household size on adoption and those of Suh (1976), Yim (1978) and Flinn et al., (1980) who found no significant impact of household size on adoption. Yim (1978) specifically reported that household size is an insignificant variable in fertilizer use. Education was, positively related with adoption in Funtua and Ajiwa Zones as well as in the pooled result, but was negatively related with adoption in Rano and Danbatta zones. A positive coefficient for education implies that adoption increases with higher level of educational attainment. The argument is that higher education levels are associated with greater information on conservation measures and the productivity consequences of land degradation, as well as higher management expertise (Hoover and Wiitala,1980; Ervin and Ervin, 1982; Feder et al., 1985). Some studies (Voh, 1979; Rogers, 1983; Rahmand Huffman, 1984; Atala, 1984; Kebede et al., 1990; Adesina and Seidi, 1995; Norris and Batie, 1987; Pender and Kerr, 1996; Saito, 2004) have found a positive relationship between education and the adoption of technologies and soil conservation effort. A negative coefficient for education implies that higher education is associated with lower levels of adoption. The reason may be that higher education provides opportunities to individuals to acquire knowledge about more lucrative non-farm business opportunities, as a result of which the adoption of farm-related innovations will lessen. Membership of association's was, as hypothesized, positively related with adoption in Rano and Ajiwa zones, significantly and positively related with adoption in Funtua zone as well as in the pooled result for all the locations, but was negatively related with adoption in Danbatta zone. A positive sign for the membership of farmers' groups suggests that the longer the membership of farmers' groups, the greater the level of adoption. The membership of associations enhances access to information on improved technologies, material inputs of the technologies such as chemical fertilizer, as well as credit for the purchase of inputs (Njoku, 1990; Akpoko and Yiljep, 2000). Studies elsewhere (Sajise and Ganapin, 1991; Gabunada and Barker, 1995) have found membership in farmers' groups to be positively correlated with adoption. Farm size, consistent with expecta- tions, related with adoption in all the sampled locations but was significantly related only in Ajiwa zone and in the pooled result for the zones. A positive sign for the farm size variable implies that adoption increases with expansion in farm size. The argument is that farm size is often correlated with peasant wealth that may help ease liquidity constraints (Shiferaw and Holden, 1998). Similarly, wealt hier farmers are more likely to be able to apply expensive fertilizer on their farms (Nkonya et al., 1997). Besides, large farmers generate more income which provides a better capital base and enhances risk-bearing ability (Asaduz zaman, 1979; Sarap and Vashist, 1994). Previous researches (Ervin and Ervin, 1982; Feder and Slade, 1984; Norris and Batie, 1987; Gould et al., 1989; Polson and Spencer, 1991) have also found a positive role of farm size on conservation decisions. Credit was posi tively related with adoption of inorganic fertilizer across the sampled locations except in Danbatta zone where no credit was obtained but was significantly related only in the pooled result. A positive credit coefficient indicates that the greater the supply of credit, the higher the adoption. The argument is that the availability of credit either in cash or kind enhances farmers' ability to purchase or acquire inorganic fertilizer (Akpoko and Yiljep, 2000). Some studies (Njoku, 1990; Chikwendu et al., 1993; Agada et al., 1991; Akpoko and Yiljep, 2000) have found credit to be positively associated with adoption. Off-farm income was, as expected, positively related with adoption in Rano and Ajiwa zones, but was negatively related with adoption in Danbatta and Funtua zones as well as well as in the pooled result. A negative and significant relationship was, however, observed only in Funtua and in the pooled result. A positive coefficient for off-farm income suggests that the larger the income earned from non-farm sources, the greater the level of adoption. The argument is that offfarm income may ease the liquidity constraint needed for soil-conservation investments or purchase of fertility-enhancing inputs (Shife raw and Holden, 1998). A negative coefficient for off-farm income, on the other hand, implies that increases in off-farm income will be accompanied by reductions in the levels of adoption. The reason is that off-farm investment may crowd out investment resources for landquality improvement and that increasing de- 
pendence on non-agricultural activities may translate into a shift of interest away from farming (Shively, 1997; Shiferaw and Holden, 1998). The extension contact variable, as expected, was positively related with adoption in Funtua, Ajiwa (where it was also significantly related) and in the pooled result for the zones, but was negatively related with adoption in Rano and Funtua zones. A positive sign for extension contact means that adoption increases with greater extension contact. Extension contacts, by exposing farmers to availability of information, stimulate adoption (Voh, 1979; Kebede et al., 1990; Polson and Spencer, 1991). A negative sign for extension contact shows that the greater the extension contact, the lower the adoption of inorganic fertilizer. This may be because greater access to information on better non-farm investment opportunities from more extension contact reduces the likelihood of investments in farming-related technologies. The land security variable was negatively related with adoption in all the sampled locations but was significantly and negatively related only in Ajiwa zone and in the pooled result for the locations. A negative coefficient for the land security variable implies that more ownership of land is associated with lower adoption. The reason is that the improved access to credit and liquidity from assured security of use rights over land makes low-income households much more inclined to invest in more profitable non-agricultural ventures than in farm technologies for soil conservation.

\section{CONCLUSION \& RECOMMENDATI ONS}

The paper investigated the rates of adoption and application of inorganic fertilizer and the factors associated with its adoption for land management in the north-west zone of Nigeria. Though adoption rates of inorganic fertilizer varied by location, the calculated rates of adoption (Table 3) are a confirmation of its importance as a crucial ingredient in the process of increasing agricultural productivity. The computed rates of application of inorganic fertilizer (Table 3) are much lower than the recommended rates of application, thus indicating that its yield-and soil-enriching potentials were not fully realized. All the farmer - and farm structural characteristics included in our model (Table 5) had positive, negative and in some cases, both positive and negative effects on adoption, thus supporting conclusions reached in innovation - diffusion and adoption literature to the effect that farmers' socio-economic characteristics explain technology adoption decisions. The following recommendations are important:-

1. Given that fertilizer requirements for crops were not and are not likely to be met by farmers, particularly with the reduction, and in some cases phrasing out of fertilizer subsidy, the complementary applications of both inorganic and organic fertilizers will be very useful. Valauwe et al., (2002) reported positive interactions between urea and use of stover and other organic applications, while Nhamo (2001) observed added benefits from manure and ammonium intake combinations. Similarly, more appropriate soil and crop management systems need to be developed so as to reduce the amount and frequency of application of inorganic fertilizers while also increasing efficiency of their utilization by crops. The increasing acceptance of integrated soil fertility management (ISFM) practices by small-holder farmers need to be encouraged as it expands the choice set of farmers by increasing their awareness of the variety of options available and how they may complement or substitute for one another (Place et al., 2003). The ISFM paradigm acknowledges the need for both mineral and organic inputs to sustain soil health and crop production due to positive interactions and complementarities between them (Buresh et al., 1997; Vanlauwe et al., 2002).

2. Having established that the socio-economic factors of farmers affect the adoption of inorganic fertilizer, extension educators and technical assistants involved in agricultural development need to understand these factors inorder to target and deliver effective programmes. A knowledge of these factors is also necess

3 . The positive and significant relationship between the education variable and the adoption of inorganic fertilizer in the results makes the education of the rural populace particularly necessary. Education raises the productivity of farmers in the agricultural production process, increases the rate of return to investments in new production and conservation technologies and facilitates the adjustment of labour out of the agricultural sector. The improvement of the literacy skills of farmers and farm workers 
alike will allow for proper handling and application of inorganic fertilizer.

4. The positive and significant relationship between the education variable and the adoption of inorganic fertilizer in the results makes the education of the rural populace particularly necessary. Education raises the productivity of farmers in the agricultural production process, increases the rate of return to investments in new production and conservation technologies and facilitates the adjustment of labour out of the agricultural sector. The improvement of the literacy skills of farmers and farm workers alike will allow for proper handling and application of inorganic fertilizer.

5 . The positive and significant relationship between membership of farmers' associations and adoption of inorganic fertilizer suggests that efforts be made to encourage greater and longer membership of farmers' groups. Farmers' cooperative associations provide farmers with many production supplies for their farm operations such as fertilizers, feed, seeds, farm chemicals; help market products members produce, and also provide services related to the production and marketing of farm commodities such as credit, irrigation, pest management, and plant and animal research. It is easier for government assistance to reach widely dispersed smallholders when they organize themselves properly into coherent groups such as cooperatives and these also serve as media for wider and cheaper dissemination of information on new technologies (Njoku, 1990).

6 . The positive and significant effect of farm size on adoption of inorganic fertilizer, means that expansions in existing farm sizes through purchases of additional land, or the consolidation of existing holdings are important. As a factor of production and a store of wealth, land provides collateral and is one of the few sources of credit and liquidity for poor farmers. 7. The positive and significant influence of credit on adoption of inorganic fertilizer makes improved access to production credit with low transaction costs an important requirement. Inorganic fertilizer options are commonly less affordable to cash - strapped households than organic nutrient systems. The terms of credit should reflect the fact that much of the returns to land-conserving practices accrue over a long time. This is particularly critical because many studies have found that poor farmers' inability to access mineral fertilizers has adverse conse- quences on soil fertility and incomes (Soule and Shepherd, 2000). Thus, credit arrangements and/or other means of assisting farmers to make necessary capital improvements should be designed so that society shares some portion of the cost with farmers, since some of the long-term benefits of resource conservation will also be enjoyed by society (Jayne et al., 1989). The positive and significant effect of extension contact on adoption of inorganic fertilizer is indicative that extension systems must be strengthened to increase farmer knowledge and understanding of mineral fertilizer sources and other related technological options in a timely and accurate manner using the most appropriate communication and training methods and eliciting information about farmers' concerns and problems with these technologies and conveying them to research and technology centres. Collaborating with farmers and researchers in the development of these technologies in response to today's rapidly changing circumstances would also be extremely useful.

\section{REFERENCES}

Adesina, A.A. and Baidu-Forson, J. (1995) Farmers' perceptions and adoption of new agricultural technology: Evidence from analysis in Burkina Faso and Guinea, West Africa, Agricultural Economics, 13: 1 - 9.

Adesina, A.A. and Zinnah, M.M. (1993) Technology characteristics, farmers' perceptions and adoption decisions: A Tobit model application in Sierra Leone, Agricultural Economics, 9: $297-311$.

Adesina, A.A. and Seidi, S. (1995) Farmers' perceptions and adoption of new agricultural technology: Analysis of modern mangrove rice varieties in Guinea Bissau, Q.J. Int. Agric., 34: 358 - 385.

Agada, J.E., Phillip, D. and Musa, R.S. (1997) A logit model for evaluating poultry farmers' participation in the agricultural insurance scheme in Kaduna State, Nigeria, $\mathrm{Ni}$ gerian Journal of Rural Economy and Society, 1(3): $49-55$.

Ahmed, M.M. and Sanders, J.H. (1991) The economic impacts of Hageen Dura -1 in the Gezira scheme, Sudan, Proceedings, International Sorghum and Millet CRSP conference, Corpus Christi, Texas, July 8 12, 1991. 
Akino, M. and Hayami, Y. (1975) Efficiency and equity in public research: Rice breeding in Japan's economic development, Amer. J. Agr. Econ., 57 (10: 1 - 10.

Akpoko, J.G. and Yiljep, Y.D. (2000) Factors associated with the adoption of treadle pump technology in the north-west part of Nigeria, Science Forum: Journal of Pure and Applied Sciences, 3(1): $70-78$.

Alao, J.A. (1971) Communication structure and modernization of agriculture: An analysis of factors influencing the adoption of farm practices among Nigerian farmers, Unpublished Ph.D. thesis, Cornell University, Ithaca, New York.

Asaduzzaman, M. (1979) Adoption of HYV rice in Bangladesh, Bangladesh Dev. Stud., 7: $23-25$.

Ashby, J. and Sperking, L. (1992) Institutionalizing participatory, client - driven research and technology development in agriculture, Paper presented at the meeting of the CGIAR social scientists, The Hague, The Netherlands, September 15-22, 1992.

Ashby, J.A., Quiros, C.A. and Rivers, Y.M. (1989) Farmer participation in technology development: Work with crop varieties. In Farmer First: Farmer Innovation and Agricultural Research, Intermediate Technology Publications, London.

Atala, T.K. (1984) The relationship of socioeconomic factors in agricultural innovations and utilization of information sources in two Nigerian villages, The Nigerian Journal of Agricultural Extension, 2 (1 and 2): $1-10$.

Atala, T.K. (1988) A study of Factors Related to Adoption of Agricultural Innovations and Level of Living among Maigana and Gimba Farmers, Samaru Miscellaneous $\mathrm{Pa}-$ per 124, Institute for Agricultural Research, Ahmadu Bello University, Zaria, Nigeria.

Atala, T.K. and Abdullah, Y.A. (1988) Adoption behaviour of peasant farmers with regards to improved cropping systems: A case study of northern Nigeria. In Improved Agricultural Technologies for small-scale Nigerian Farmers, G.O.I. Abalu and B.A. Kalu (eds.). Proceedings of the National Farming systems Research Network Workshop held in Jos, Plateau State, Nigeria, May 10-13, 1998.

Baidu-Forson, J. (1999) Factors influencing adoption of land-enhancing technology in the Sahel: Lessons from a case study in Niger, Agricultural Economics, 230: 231 239.

Barbier, E.B. (1998) The Economics of land degradation and rural poverty linkages in Africa, United Nations University (UNU)/ Institute for Natural Resources in Africa (INRA) annual lectures, public affairs section, The United Nations University, Shibuya-ku, Japan, 1998.

Basu, A.C. (1969) The relationship of farmers' characteristics to the adoption of recommended farm practices in four villages of the Western State of Nigeria, Bulletin of Rural Economics and Sociology, 4(1): $79-$ 98.

Bhati, U.N. (1975) Use of high-yielding rice variety in Malaysia, The Developing Economies, 13 (2): 187 - 207.

Brady, N. (1993) Securing Sustainable Agricultural Development: The Plant Nutrient Connection, IFDC Annual Report 1992, Muscle Shoals, Ala., U.S.A. International Fertilizer Development Centre.

Bumb,B.L. and Baanante, C.L. (1996) The Role of Fertilizer in Sustaining Food Security and Protecting the Environment to 2020, Food, Agriculture, and the Environment Discussion Paper No. 17, International Food Policy Research Institute (IFPRI), Washington, D.C.

Buresh, R.J., Sanchez, P.A. and Calhoun. F. (eds.). (1997) Replenishing Soil Fertility, SSA Special publication No. 51, Soil Science Society of America, Madison, Wisconsin, USA.

Byerlee, D. and Heisey, P. (1992) Strategies for technical change in small-farm agriculture, with particular reference to subSaharan Africa. In Policy Options for Agricultural Development in sub-Saharan Africa, Russel, N.C. and Dowswell(eds.) C.R. Proceedings of a workshop, Airlie House, Virginia, August 23 - 25, 1992.

Byrnes, F.C. (1966) Some missing variables in diffusion research and innovation, Paper presented at the Philippine Sociological Association, Manila, Philippines.

Chien, S.H., Carmona, G., Menon, R.G. and Hellums, D.T. (1993) Effect of phosphate rock sources on biological nitrogen fixation by soybean, Fertilizer Research, 34: 153 159. 
Chikwendu, D.O., Amos, T.T. and Tologbonse, E.B. (1993) Farmers' response to agricultural insurance in Niger State, Nigeria, Journal of the West African Farming Systems Research Network, 5 (2): 45 - 50.

Chinnappa, B.N. (1977) Adoption of the new technology in North Arcot District. In Green Revolution Technology and Change in Rice - Growing Areas of Tamil Nadu and Sri Lanka, B.H. Farmer (ed.). Boulder, Colorado, Westview Press.

Clark, R.C. and Akinbode, L.A. (1968) Factors Associated with Adoption of Three Farm Practices in the Western State of Nigeria, Research Bulletin 1, Faculty of Agriculture, University of Ife, Ile-Ife, Nigeria.

Coughenour, C.M. (1960) The functioning of farmers' characteristics in relation to contact with media and practice adoption, $R u$ ral Sociology, 25: 283 - 297.

Desai, G.M. (1990) Fertilizer policy issues and sustainable agricultural growth in developing countries. In Technology Policy for Sustainable Agricultural Growth, Policy Brief No. 7, International Food Policy Research Institute (IFPRI), Washington, D.C.

Eicher, C.K. (1994) Building productive national and international agricultural research systems. In Agriculture, Environment, and Health: Sustainable Development in the $21^{\text {st }}$ Century, V.W. Ruttan (ed.), University of Minnesota Press, Minneapolis, Minnesota.

Enwezor, W.O., Udo, E.J., Usoroh, N.J., Ayotade, K.A., Adepetu, J.A., Chude, V.O. and Udegbe, C.I. (eds.). (1989) Fertilizer Use and Management Practices for Crops in Nigeria, Fertilizer Procurement and Distribution Division, Federal Ministry of Agriculture, Water Resources and Rural Development, Lagos, Nigeria.

Ersado, L., Amacher, G. and Alwang, J. (2004) Productivity-and land-enhancing technologies in northern Ethiopia: Health, public investments, and sequential adoption, Amer.J.Agr. Econ., 86(2): 321 - 331.

Ervin, C.A. and Ervin, D.E. (1982) Factors affecting the use of soil conservation practices:Hypothesis, evidence and policy implication, Land Economics, 58(3): 272 292.

FAO (Food and Agriculture Ogranization of the United Nations). (1997) FAOSTAT Statistical Database 1997, FAO, Rome, Italy.
FAO (Food and Agriculture Organization of the United Nations). (1993) Agriculture Towards 2010, FAO, Rome, Italy.

Feder, G. and Slade, R. (1984) The acquisition of information and the adoption of new technology, Amer. J. Agr. Econ., 66: 312 320.

Feder, G., Just, R. and Zilberman, D. (1985) Adoption of agricultural innovations in developing countries: A survey, Economic Development and Cultural Change, 33: 255 $-298$.

Flinn, J.C., Karki, B., Rawal, T., Masicat, P. and Kalirajan. (1980) Rice Production in the Tarai of Kosi Zone, Nepal, International Rice Research Institute Research Paper No. 54.

Floyd, C.N., Harding, A.H., Paddle, K.C., Rasali, D.P., Subedi, K.D. and Subedi, P.P. (1999) The adoption and associated impact of technologies in the western hills of $\mathrm{Ne}$ pal, Overseas Development Institute Agricultural Research and Extension Network Paper No. 90.

Gabunada, F. and Barker, R. (1995) Adoption of contour hedgerow technology in Mataham, Leyte, Philippines, Mimeo.

Gould, B.W., W.E. Saupe and R.M. Klemme. 1989. Conservation tillage: The role of farm and operator characterstics and the perception of erosion, Land Econ., 65: 1657-182.

Heisey, P. and Mwangi, W. (1993) An overview of measuring research impact assessment. In Impacts on Farm Research, Heisey, P. and Waddington, S. (eds.) Proceedings of a Networkshop on Impacts on Farm Research in Eastern Africa, CIMMYT Eastern and Southern Africa OnFarm Research Network Paper No. 24, Harare, Zimbabwe.

Herdt, R.W. and Capule, C. (1983) Adoption Spread, and Production Impact of Modern Rice Varieties in Asia, International Rice Research Institute, Los Banos, Laguna, Philippines.

Hoover, H. and Wiitala, M. (1980) Operator and Landlord Participation in Soil Erosion in the Maple Creek Watershed in Northeast Nebraska, U.S. Department of Agriculture, Washington, D.C.

IBSRAM (International Board for Soil Research and Management). (1987) Management of Acid Tropical Soils for Sustainable 
Agriculture, Proceedings of an IBSRAM inaugural workshop, Bangkok, Thailand.

Idisi, P.O. (1990) The potential for hybrid maize production in the northern Guinea Savanna of Nigeria:A comparative study with the open-pollinated maize varieties, Unpublished M.Sc. thesis, Ahmadu Bello University, Zaria, Nigeria University, Zaria, Nigeria.

Islam,M.M. and Halim, A. (1976) Adoption of IRRI Paddy in a Selected Union of Bangladesh, Bangladesh Agricultural University.

Jayne, T.S., Day, J.C. and Dregne, H.E. (1989) Technology and Agricultural Productivity in the Sahel, Agricultural Economic Report No. 612, Economic Research Service, United States Department of Agriculture, Washington, D.C.

Jigawa Agricultural and Rural Development Authority (JARDA). (1996) Agricultural Extension Manual on Crops, Livestock and Fisheries, JARDA.

Kebede, Y., Gunjal, K. and Coffin, G. (1990) Adoption of new technologies in Ethiopian agriculture: The case of Tegulet-Bulga district, Shoa Province, Agricultural Economics, 4: $27-43$.

Lapar, M.L.A. and Pandey, S. (1999) Adoption of soil conservation: The case of the Philippine uplands, Agricultural Economics, 21: 241 - 256.

Lele, U., Christiansen, R.E. and Kadiresan, K. (1989) Fertilizer Policy in Africa: Lessons from Development Programmes and Adjustment Lending, 1970 - 87, MADIA Discussion Paper No. 5, The World Bank, Washington, D.C.

Liao, D.S.N. (1968) Studies on adoption of new rice varieties, Paper presented at the IRRI Saturday Seminar, November 1968.

Lopez-Pereira, M.A., Gonzalez-Rey, D. and Sanders, J.H. (1991) The impacts of new Sorghum cultivars and other associated technologies in Honduras, Proceedings of the International Sorghum and Millet CRSP Conference, Corpus Christi, Texas, July 812, 1991.

Mangahas, M. (1970) An economic analysis of the diffusion of new rice varieties in central Luzon, Unpublished Ph.D. dissertation, University of Chicago.

Mitchell, D.O. and Ingco, M.D. (1993) The World Food Outlook, The World Bank, Washington, D.C.
Musa, M.W. ands Atala, T.K. (2004) Complementary use of indigenous and modern technical knowledge as best practices for sustainable agricultural development: A case study. In Indigenous Knowledge and sustainable Agricultural Development in Nigeria, C.P.O. Obinne, B.A. Kalu and J.C. Umeh (eds.), Proceedings of the National Conference on Indigenous knowledge and Development, Cekard Associates, 2004.

National Agricultural Research Project. (1995) Draft Report of the National Agricultural Research Strategy Plan: Volume 1, Federal Department of Agriculture and Natural Resources, Lagos, Nigeria.

Nhamo, N. (2001) An evaluation of the efficacy of organic and inorganic fertilizer combinations in supplying nitrogen to crops , Unpublished M.Phil. Thesis, University of Zimbabwe, Harare, Zimbabwe.

Njoku, J.E. (1990) Factors influencing the adoption of improved oil palm production technologies by smallholders in Imo State of Nigeria. In Appropriate Agricultural Technologies for Resource-Poor Farmers, Olukosi,, J.O. Ogungbile, A.O. and Kalu, B.A. (eds.), Proceedings of the National Farming systems Research Network Workshop held in Calabar, Cross-River State, Nigeria, August 14 - 16, 1990.

Nkonya, E., Schroeder, T. and Norman, D. (1997) Factors affecting adoption of improved Maize seed and fertilizer in Northern Tanzania, Journal of Agricultural Economics, 48(1): 13-21.

Norris, P.E. and Batie, S.S. (1987) Virginia farmers' soil conservation decisions:An application of Tobit analysis, South. J. Agric. Econ., 19:79- 89.

Nowak, P.J. (1987) The adoption of agricultural conservation technologies: Economic and diffusion explanations,' Rural Sociol., 52: $208-220$.

Ogungbile, A.O., Tabo, R. and van Duivenbooden, N. (1999) Multi-scale Characterization of Production Systems to Prioritize Research and Development in the Sudan Savanna Zone of Nigeria, Information Bulletin No. 56, International Crops Research Institute for Semi-Arid Tropics (ICRISAT), Patancheru, Andhra Pradesh, India.

Omiti,J.M., Freeman, H.A., Kaguongo, W. and Bett., C. (1999) Soil Fertility Maintenance in Eastern Kenya:Current practices, 
Constraints, and Opportunities, CARMASAK Working Paper No.1, KAR/ICRISAT, Kenya.

Onwueme, I.C. and Sinha, T.D. (1991) Field Crop Production in Tropical Africa: Principles and Practice, Technical Centre for Agricultural and Rural Cooperation

Pander, J. and Kerr, J. (1996) Determinants of Farmers' Indigenous Soil and Water Conservation Investments in India's SemiArid Tropics, EPTD Discussion Paper No. 17, International Food Policy Research Institute (IFPRI), Washington, D.C.,

Phillip, D., Maiangwa, M. and Phillip, B. (2000) Adoption of Maize and related technologies in the north-west zone of Nigeria, Moor Journal of Agricultural Research, 1: $98-105$.

Pinstrup-Andersen, P. and Pandya-lorch, R. (1994) Alleviating Poverty, Intensifying Agriculture, and Effectively Managing Natural Resources, Food, Agriculture, and the Environment Discussion Paper No. 1, International Food Policy Research Institute, Washington, D.C.

Place, F., Barrett, C.B., Ade Freeman, H., Ramisch, J. and Vanlauwe, B. (2003) Pros pects for integrated soil fertility management using organic and inorganic inputs: Evidence from smallholder African agricultural systems, Food Policy 28: 365 - 378.

Polson R.A. and Spenser, D.S.C. (1990) The technology adoption process in subsistence agriculture: The case of cassava in southwestern Nigeria, Agricultural Systems, 36 (1): $65-78$.

Rahm, M. and Huffman, W. (1984) The adoption of reduced tillage: The role of human capital and other variables. Amer. J. Agr. Econ., 66: 405 - 413.

Ramswamy, D. 1993. Adoption incentives related to packages of practices of highyielding varieties in Mysore State, India, Unpublished Ph.D. thesis, Cornell University, Ithaca, New York.

Ranaivoarison, R. (2004) Land property rights and agricultural development in the highlands of Madagascar: Economic and environmental implications. In Farming and Rural systems Economics, W. Doppler and S. Bauer (eds.). Margraf Publishers.

Reardon, T., Barrett, C.B., Kelly, V. and Savadogo, K. (1999) Sustainable versus unsustainable agricultural intensification in Af- rica: Focus on policy reforms and market conditions, In Agricultural Intensification, Economic Development and the Environment, Forthcoming.

Rogers, E.M. (1983) Diffusion of Innovations, John Wiley and Sons, New York.

Rogers, E.M. and Burdge, R.J. (1977) Community norms, opinion leadership and innovativeness among truck growers, Ohio Agricultural Experiment Station Research Bulletin. 37: $1-5$.

Rosegrant, M.W., Agcaali-Sombilla, M. and Perez, N.D. (1995) Global Food Projections to 2020: Implications for investment, Food, Agriculture, and the Environment Discussion Paper No. 5, International Food Policy Research Institute, Washington, D.C.

Saito, K. (1994) Raising the Productivity of Women Farmers in sub-Saharan Africa, Discussion Paper No.203, The World Bank, Washington, D.C.

Sajise, P. and Gawapin, D. (1991) An overview of upland development in the Philippines . In Technologies for Sustainable Agriculture on Marginal Uplands in Southeast Asia, G. Blair and R. Lefroy (eds.), ACIAR Proceedings No. 33, Australian Centre for International Research.

Sarap, K. and Vashist, D.C. (1994) Adoption of modern varieties of rice in Orissa: A farmlevel analysis. India J. Agric. Econ., 49: 88 $-93$.

Shiferaw, B. and Holden, S.T. (1998) Resource degradation and adoption of land conservation technologies in the Ethiopian highlands: A case study in Andit Tid, North Shewa, Agricultural Economics, 18: 238247.

Shively, G.E. (1997) Consumption risk, farm characteristics and soil conservation adoption among low-income farmers in the Philippines, Agricultural Economics, 17: 165-177.

Sombroek, W.G. (1994) Aspects of Soil organic matter and nutrient cycling in relation to climate change and agricultural sustainability , Paper presented at the International Symposium on Nuclear and Related Techniques in Soil/Plant Studies on Sustainable Agriculture and Environmental Preservation, held jointly by the International Atomic Energy Agency and the Food and Agriculture Organization of the United Nations, Vienna, Austria. 
Soule, M. and Shepherd, K.D. (2000) An ecological and economic analysis of phosphorus replenishment for Vihiga Division, western Kenya , Agricultural Systems, 64: $83-98$.

Vanlauwe, B., Diels, J., Sanginga, N. and Merckx, R. (2002) Integrated Plant Nutrient Management in Sub-Saharan Africa: From concept to Practice, CABI, Wallingford, U.K.

Voh, J.P. (1979) An Exploratory Study of Factors Associated with Adoption of Recommended Farm Practices Among Giwa Farmers, Samaru Miscellaneous Paper No.73, Institute for Agricultural Research, Ahmadu Bello University, Zaria, Nigeria.

World Bank. (1986) Internal Memorandum. July 17, 1986.
Yim, K.M. (1978) An economic analysis of factors affecting HYV and fertilizer adoption in the province of Negeri Sembilan, Peninsular Malaysia, Unpublished M.Sc. thesis, University of the Philippines, Los Banos, Philippines.

Zurek, M.B. (2002) Induced innovation and productivity - enhancing, resourceconserving technologies in Central America: The supply of soil conservation practices and small-scale farmers' adoption in Guatemala and El Salvador, Unpublished Ph.D. thesis, Justus-Liebig University, Giessen, Germany. 